\title{
УДОСКОНАЛЕННЯ СИСТЕМИ РОЗВИТКУ ПЕРСОНАЛУ НА ПІДПРИЕМСТВІ
}

\section{IMPROVEMENT OF THE PERSONNEL DEVELOPMENT SYSTEM AT THE ENTERPRISE}

\author{
Якимова Наталія Сергіївна \\ доктор економічних наук, доцент, \\ Донецький національний університет імені Василя Стуса \\ ORCID: https://orcid.org/0000-0001-5278-1142 \\ Марценюк Олеся Віталіївна \\ старший викладач, \\ Донецький національний університет імені Василя Стуса \\ ORCID: https://orcid.org/0000-0003-3871-1599 \\ Мойсєєва Валерія Олегівна \\ студентка, \\ Донецький національний університет імені Василя Стуса \\ ORCID: https://orcid.org/0000-0002-0782-5086
}

\author{
Yakymova Nataliia, Martseniuk Olesia, Moisieieva Valeriia \\ Vasyl' Stus Donetsk National University
}

\begin{abstract}
У статті досліджено сучасні проблеми системи розвитку персоналу підприємства, висвітлено специоріку, негативні та позитивні тенденції цього процесу. Визначено, що реалізація системи розвитку персоналу на підприємстві здійснюється виходячи зі стратегії його розвитку, специсріки діяльності, комунікаційної спрямованості, особливостей зовнішнього середовища. Запропоновано алгоритм розвитку персоналу підприємства. У ході реалізації заходів щодо розвитку персоналу доведено, що важливо забезпечити охоплення цими заходами основних аспектів управління персоналом підприємства, зокрема процесів оцінки персоналу, відбору, адаптації, планування ділової кар'єри, роботи з кадровим резервом з використанням сукупності різних методів. Виокремлено методи розвитку персоналу підприємства, що відрізняються часовим періодом, матеріальними витратами та ефективністю. Закцентовано увагу, що при виборі найбільш прийнятного методу необхідно враховувати його переваги та недоліки.
\end{abstract}

Ключові слова: персонал, розвиток персоналу, система розвитку персоналу, алгоритм, методи розвитку персоналу, стратегії розвитку.

В статье исследованы современные проблемы системы развития персонала предприятия, отражена специфика, негативные и позитивные тенденции этого процесса. Установлено, что реализация системы развития персонала на предприятии осуществляется на основе стратегии его развития, специфики, коммуникационной направленности, особенностей внешней среды. Предложен алгоритм развития персонала предприятия. В ходе реализации мероприятий по развитию персонала доказано, что важно обеспечить охват этими мероприятиями основных аспектов управления персоналом предприятия, в частности процессов оценки персонала, отбора, адаптации, планирования деловой карьеры, работы с кадровым резервом с использованием совокупности различных методов. Выделены методы развития персонала предприятия, отличающиеся временным периодом, материальными затратами и эффективностью. При выборе наиболее приемлемого метода необходимо учитывать его преимущества и недостатки.

Ключевые слова: персонал, развитие персонала, система развития персонала, алгоритм, методы развития персонала, стратегия развития.

The article examines the current problems of the personnel development system of the enterprise, highlights the specifics, negative and positive trends of this process. It is determined that the implementation of the personnel development system at the enterprise is carried out based on the strategy of its development, features, communication orientation, features of the external environment. The algorithm of development of the personnel of the enterprise is 
offered, considering the following stages: definition and systematization of problems in work of the personnel, and also identification of sources of their occurrence; determining the need for staff development of the enterprise (training, motivation, incentives, professional development); identification of goals, principles and methods of staff development; development of the program (plan, strategy) of development of the personnel of the enterprise; formation of resource support for the implementation of the proposed measures for staff development (equipment, materials, premises, personnel, finance); control over the implementation of the program (plan, strategy) of staff development, monitoring and evaluation of learning outcomes and staff development; assessment of the level of influence of new acquired knowledge, skills and abilities on the results of the staff of the enterprise. During the implementation of personnel development measures, it is important to ensure that these measures cover the main aspects of personnel management, including the processes of personnel evaluation, selection, adaptation, career planning, work with the personnel reserve using a set of different methods. The methods of enterprise personnel development, which differ in time period, material costs and efficiency, are singled out. They are divided into group (trainings, master classes, professional seminars, advanced training and retraining courses), individual (delegation of authority, planning and career development of staff, projects and tasks, internships, mentoring, coaching) and remote (online training, e-mailing of classes, lectures, tasks, tests, online courses and programs). It is emphasized that when choosing the most acceptable method it is necessary to take into account its advantages and disadvantages.

Keywords: personnel, personnel development, personnel development system, algorithm, personnel development methods, development strategy.

Постановка проблеми. В умовах цисррової трансформації економіки розвиток персоналу $є$ одним із актуальних питань у сорері управління персоналом, які стоять перед керівництвом незалежно від того, на якій стадії розвитку перебуває підприємство. Грамотно спланована та чітко організована робота з розвитку персоналу сприяє досягненню стратегічних цілей підприємства, підвищенню його конкурентоспроможності, а також готовності до проведення організаційних змін. Таким чином, актуальність дослідження процесів удосконалення системи управління розвитком персоналу обумовлена відсутністю в економічній літературі чітко описаного механізму реалізації даного процесу на корпоративному рівні, необхідністю виявлення чіткого взаємозв'язку стратегії розвитку підприємства та заходів, спрямованих на формування його кадрового потенціалу. Тобто, ефрективно побудована система розвитку персоналу на підприємстві $€$ ключем до еорективної конкурентоспроможної діяльності та способу досягнення поставлених цілей.

Аналіз останніх досліджень і публікацій. Дослідженню проблем управління та розвитку персоналу присвячено праці відомих науковців, таких як: І. Ансоффф, М. Армстронг, Г. Бей [1], В. Брич [2], Р. Вундерер, Б. Генкін, О. Грішнова [3], І. Грузіна [4], Г. Десслер, П. Друкер, А. Єгоршин, А. Кібанов, Т. Максимова, Ю. Одєгов, Г. Осовська, І. Петрова, М. Прокопенко, М. Семикіна [5], А. Томпсон, А. Чухно, Л. Шаульська [6] та інші.

Виділення невирішених раніше частин загальної проблеми. Сьогодні проблема фрормування та розвитку системи управління персоналом залишається актуальною та потребує розробки дієвих механізмів, що забезпечать побудову ефективної системи розвитку персоналу на підприємстві.

Формулювання цілей статті (постановка завдання). Метою статті $\epsilon$ дослідження питання розвитку персоналу та розробка перспективних напрямів та механізмів удосконалення системи розвитку персоналу на підприємстві.

Виклад основного матеріалу дослідження. Персонал - одна з найважливіших і складних складових структури підприємства. Адже, на відміну від технологічного оснащення підприємства, співробітники здатні самостійно приймати рішення, враховуючи, в першу чергу, свої особисті мотиви та емоції. До того ж кадри складають робочий колектив, який дуже важливий для підприємства, що успішно розвивається, і при цьому кожен його член має свої вимоги, інтереси та здібності. Завдяки ефективності роботи співробітників підвищується продуктивність підприємства, відбувається його зростання та фрормування репутації на ринку. Тому для контролю та створення зацікавленості у роботі у колективу, HR-срахівцями були розроблені різні методики, прийоми та технології. Саме вони й становлять основу системи управління та розвитку персоналу підприємства.

Сучасні прийоми управління кадрами на підприємстві засновані, насамперед, на визнанні значущості та важливості кожного окремого співробітника. Тому важливо вміти правильно використовувати особистісні характеристики, цілі, навички та вміння працівника для виконання завдань, що стоять перед підприємством. Керівник, який бажає побудувати прибуткове підприємство, що роз- 
вивається, повинен звертати увагу не тільки на те, як швидше заробити, а й на те, як стимулювати і мотивувати співробітників на виконання поставлених завдань швидко та якісно.

Отже, під розвитком персоналу розуміють проведення різних заходів, що сприяють повноцінному розкриттю кадрового потенціалу підприємства, особистісному зростанню та розвитку кожного співробітника для внесення особистого вкладу в діяльність підприємства.

Процес розвитку персоналу є сорерою теоретичних і практичних знань, що мають на меті забезпечення підприємства ефективним персоналом, його раціональне використання та всебічний розвиток. У свою чергу, система розвитку персоналу $є$ одною з основних підсистем системи управління всім підприємством. Отже, її створення, дослідження та постійне вдосконалення з урахуванням мінливого зовнішнього та внутрішнього середовища підприємства стає необхідною реальністю для фахівців з управління персоналом та керівників підприємства.

До основних цілей системи розвитку персоналу підприємства можна віднести: підвищення конкурентоспроможності підприємства на ринку; підвищення продуктивності праці та якості результатів виробництва, і як наслідок, збільшення прибутку. Реалізація системи розвитку персоналу на підприємстві здійснюється виходячи зі стратегії його розвитку, специфріки діяльності, комунікаційної спрямованості, особливостей зовнішнього середовища.
Стратегія розвитку персоналу - це узагальнююча модель дій, спрямованих на фрормування сукупності вимог до персоналу та рівня ефективності його роботи, який необхідний підприємству для досягнення поставлених бізнес-цілей.

Стратегічний аспект розвитку персоналу визначає місце стратегії розвитку в системі управління персоналом підприємства та передбачає: управління персоналом, спрямоване на підвищення адаптаційних здібностей підприємства в умовах зовнішнього середовища, що змінюється; процесуальні фрункції, що включають визначення кадрових потреб, підбір, найм, розвиток, нарощування потенціалу та ефективне використання персоналу; профрільні фрункції - контролінг, маркетинг, інфрормаційне обслуговування та організація управління розвитком персоналу.

Розвиток персоналу тісно пов'язаний 3 іншими аспектами роботи 3 персоналом та базується на потребах підприємства загалом. При цьому стратегія управління персоналом підприємства може включати залежно від ситуації (поєднання фракторів зовнішнього і внутрішнього середовища) кілька альтернативних стратегій розвитку персоналу (табл. 1).

Управління розвитком персоналу на підприємстві - це процес, в основу якого закладено аналітичну базу, що включає: визначення потреби в персоналі; проведення оцінки заходів у підборі персоналу

\section{Стратегії розвитку персоналу підприємства}

Таблиця 1

\begin{tabular}{|c|c|}
\hline Стратегія & Зміст \\
\hline $\begin{array}{l}\text { Стратегія концентрованого } \\
\text { розвитку }\end{array}$ & $\begin{array}{l}\text { Передбачає спеціалізоване навчання та просування } \\
\text { персоналу, пріоритетність розвитку окремих груп } \\
\text { персоналу підприємства }\end{array}$ \\
\hline $\begin{array}{l}\text { Стратегія розвитку } \\
\text { потенційних працівників }\end{array}$ & $\begin{array}{l}\text { Зосереджена на інтенсивних програмах навчання } \\
\text { та розвитку нещодавно прийнятих працівників, } \\
\text { профресійній орієнтації та адаптації співробітників } \\
\end{array}$ \\
\hline $\begin{array}{l}\text { Стратегія } \\
\text { диверсифікованого розвитку } \\
\text { персоналу підприємства }\end{array}$ & $\begin{array}{l}\text { Акцентує увагу на навчання та отримання додаткової } \\
\text { профресії, ротацію персоналу, програму розвитку, } \\
\text { що спрямована на покращення комунікацій, фрормування } \\
\text { команди }\end{array}$ \\
\hline $\begin{array}{l}\text { Стратегія інтегрованого } \\
\text { розвитку персоналу } \\
\text { підприємства }\end{array}$ & $\begin{array}{l}\text { Забезпечує цілісний підхід до розвитку персоналу, } \\
\text { використання спеціалізованих навчальних програм, } \\
\text { створення передумов для фрормування необхідної } \\
\text { поведінки працівників підприємства }\end{array}$ \\
\hline Кваліфрікаційна стратегія & $\begin{array}{l}\text { Спрямована на діагностику персоналу, використання } \\
\text { навчальних програм, що спрямовані на поповнення } \\
\text { відсутньої (недостатньої) кваліфрікації та характеристик } \\
\text { персоналу }\end{array}$ \\
\hline Мотиваційна стратегія & $\begin{array}{l}\text { Поєднує аналіз потреб підприємства та потенціалу } \\
\text { працівників, профресійну орієнтацію, просування персоналу } \\
\text { по кар'єрі }\end{array}$ \\
\hline
\end{tabular}




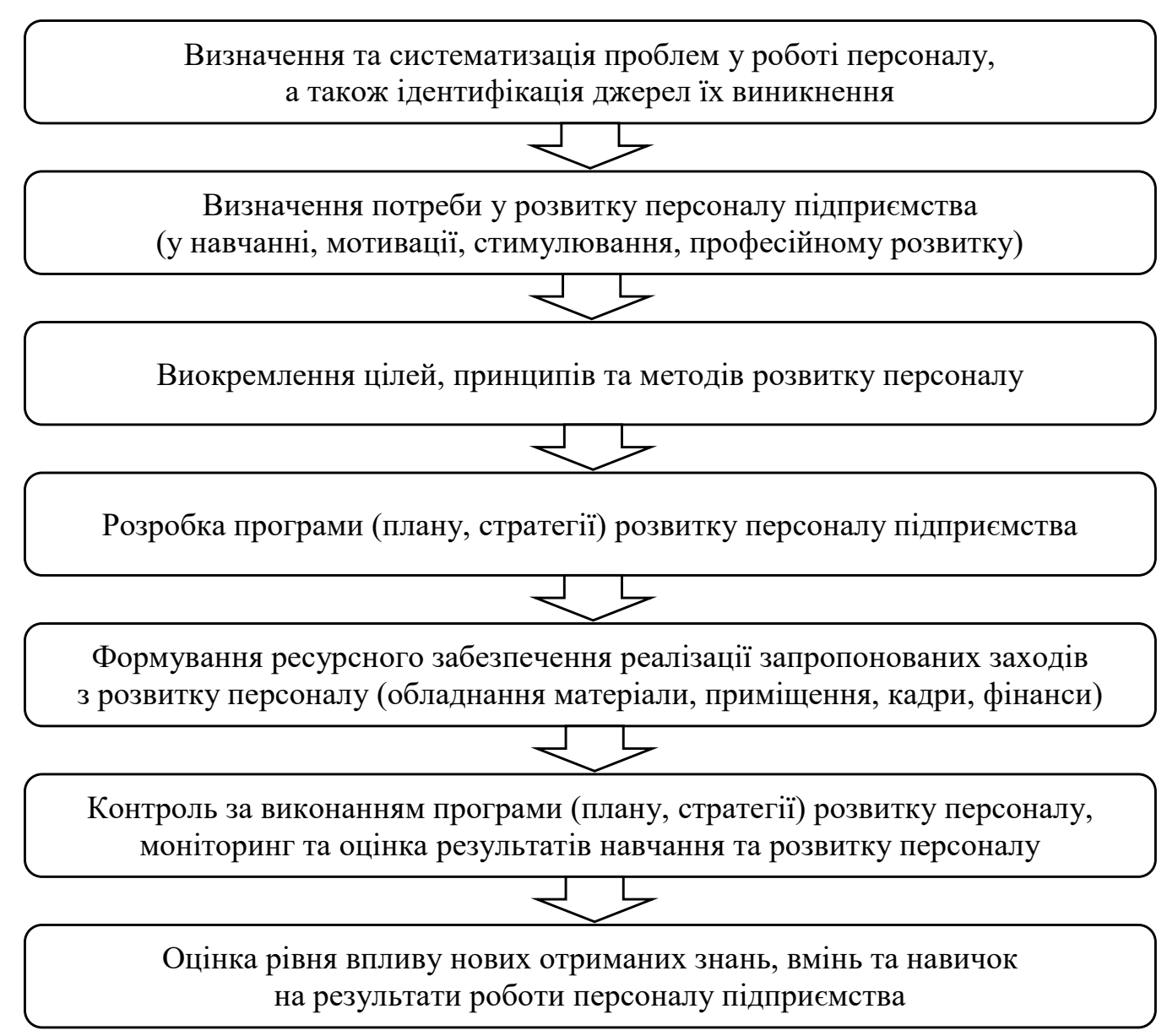

Рис. 1. Алгоритм розвитку персоналу підприємства

та його найму; оцінку складу персоналу підприємства, його якісний та кількісний аналіз; оцінку та аналіз руху персоналу; аналіз та оцінку діяльності з прогнозування, планування та управління персоналом; оцінку професійних характеристик персоналу, його відповідності посаді; визначення потреби у навчанні та розвитку співробітників. Алгоритм розвитку персоналу підприємства представлений на рис. 1.

Основна мета розвитку персоналу полягає в тому, щоб не тільки забезпечити підприємство високопрофеесійними, кваліфрікованими співробітниками, а й розвивати у співробітників потребу в постійному розвитку, зробити цей процес найважливішою структурною частиною діяльності підприємства, базової частиною його управлінського циклу.

У ході реалізації заходів щодо розвитку персоналу важливо забезпечити охоплення цими заходами основних аспектів управління персоналом підприємства, зокрема процесів оцінки персоналу, відбору, адаптації, планування ділової кар'єри, роботи з кадровим резервом 3 використанням сукупності різних методів. Методи розвитку персоналу підприємства представлені на рис. 2.

Усі виділені методи відрізняються часовим періодом, матеріальними витратами та ефективністю. При виборі найбільш прийнятного методу необхідно враховувати переваги та недоліки.

Кожне підприємство, що прагне обійти своїх конкурентів, має постійно шукати способи підвищення ефективності своєї діяльності, раціонально використовуючи у своїй діяльності всі види ресурсів. Оскільки раніше було обґрунтовано, що саме висококомпетентний персонал $є$ одним із найважливіших ресурсів підприємства, то вдосконаленню системи розвитку персоналу має приділятись особлива увага. Щоб оцінити ефективність системи розвитку персоналу на підприємстві, необхідно враховувати низку параметрів, що ґрунтуються на зборі статистичних даних за певний період.

Отже, робота з оцінки процесу розвитку персоналу може бути організована 3 різних напрямків. Відсутність загальноприйнятої методології оцінки ефективності системи розвитку 


\begin{tabular}{|c|c|c|c|}
\hline & МЕТОДИ & ПЕРЕВАГИ & НЕДОЛІКИ \\
\hline 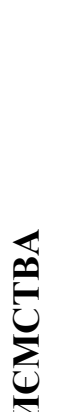 & $\begin{array}{l}\text { Групові } \\
\text { - тренінги з управлін- } \\
\text { ських та професійних } \\
\text { навичок; } \\
\text { - майстер-класи та } \\
\text { професійні семінари; } \\
\text { - курси підвищення } \\
\text { кваліфікації та пере- } \\
\text { підготовки спеціалістів }\end{array}$ & $\begin{array}{l}\text { - можливість моделю- } \\
\text { вати робочі ситуації, } \\
\text { відпрацьовувати } \\
\text { моделі поведінки; } \\
\text { - підтримка колег в } \\
\text { процесі навчання, } \\
\text { можливість отриман- } \\
\text { ня зворотного зв'язку; } \\
\text { - економія витрат }\end{array}$ & $\begin{array}{l}\text { - обмеженість час; } \\
\text { - неможливість вра- } \\
\text { хування індивідуаль- } \\
\text { них особливостей } \\
\text { кожного з учасників; } \\
- \text { рівень засвоєння } \\
\text { інформації залежить } \\
\text { від рівня початкової } \\
\text { підготовки працівника }\end{array}$ \\
\hline 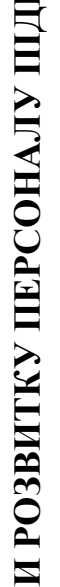 & \begin{tabular}{l}
\multicolumn{2}{c}{ Індивідуальні } \\
$-\quad$ делегування \\
повноважень; \\
- планування та \\
розвиток кар'єри \\
персоналу; \\
- проєкти та завдання; \\
- стажування; \\
- наставництво; \\
- коучинг
\end{tabular} & $\begin{array}{l}\text { - методи використо- } \\
\text { вуються під контро- } \\
\text { лем експерта, що } \\
\text { працює } 3 \text { конкретним } \\
\text { працівником; } \\
\text { - індивідуальний під- } \\
\text { хід, врахування особ- } \\
\text { ливостей та потреб; } \\
\text { - навчання може від- } \\
\text { буватися без відриву } \\
\text { від виробництва }\end{array}$ & $\begin{array}{l}\text { - висока вартість; } \\
\text { - підвищення рівня } \\
\text { навантаження на пра- } \\
\text { цівників, що викону- } \\
\text { ють роль наставника } \\
\text { або коуча }\end{array}$ \\
\hline$\sum$ & \begin{tabular}{l}
\multicolumn{2}{c}{ Дистанційні } \\
- дистанційне нав- \\
чання (онлайн-фор- \\
мат); \\
- електронна розсилка \\
занять, лекцій, завдань, \\
тестів; \\
- онлайн-курси та \\
програми
\end{tabular} & $\begin{array}{l}\text { - низька вартість та } \\
\text { доступність; } \\
\text { - контроль знань за } \\
\text { допомогою спеціаль- } \\
\text { них тестів; } \\
\text { - можливість суміщен- } \\
\text { ня роботи та навчання }\end{array}$ & $\begin{array}{l}\text { - певні труднощі у } \\
\text { розробці системи та їі } \\
\text { реалізації (технічне та } \\
\text { кадрове забезпечення) }\end{array}$ \\
\hline
\end{tabular}

Рис. 2. Методи розвитку персоналу підприємства

персоналу є основою подальшого пошуку оптимальних методик, технологій та інструментарію оцінки. Проте оцінка ефективності розвитку персоналу може виступати важелем зростання результативності управлінського процесу та ефрективності діяльності всього підприємства. Крім основної мети, вона може виявити ряд супутніх проблем, таких як невідповідність виробництва вимогам безпеки, і як наслідок, низьку ефективність праці співробітників, або занадто великі витрати, яких можна було б уникнути при грамотному управлінні.
Висновки. Таким чином, удосконалення системи розвитку персоналу підприємства це система взаємопов'язаних дій, що включають розробку стратегії, прогнозування та планування потреби в персоналі, управління кар'єрою та професійним зростанням, організацію процесу адаптації, навчання, тренінгу, формування організаційної культури. У сучасних економічних умовах управління розвитком персоналу набуває все більшого практичного значення, розглядається як фрактор підвищення конкурентоспроможності, довгостроко- 
вого розвитку підприємства. Зміни параметрів зовнішнього середовища, що відбуваються, зумовлюють необхідність осмислення характеру та причин цих змін, здійснення їх прогнозування, імітації ринкових варіантів для вибору цілей роботодавця та встановлення пріоритетів їх досягнення. Відповідно це призводить до зростання ролі стратегічного підходу до управління розвитком персоналу на підприємстві.

Підсумовуючи, можна сказати, що завданням кадрової служби та вищого керівництва будь-якого підприємства $є$ фрормування такої системи розвитку персоналу, яка б максимально сприяла підвищенню есрективності його діяльності. Грамотно побудована система розвитку персоналу підприємства, що ставить на перше місце свій персонал, його інтереси, добробут, неодмінно дозволять підприємству досягти великих успіхів. Головне ця система має бути чітко розроблена та організована, базуватися на конкретних цілях та принципах, відповідати інтересам як керівництва, так і самого персоналу, і має бути спрямована на досягнення загальних стратегічних цілей підприємства.

\section{СПИСОК ВИКОРИСТАНИХ ДЖЕРЕЛ:}

1. Бей Г.В. Управління розвитком персоналу як метод забезпечення високого рівня залученості працівників. Modern Economics. 2018. № 8. C. 6-14.

2. Брич В.Я., Гугул О.Я. Теоретичні аспекти розвитку персоналу. Вісник Хмельницького національного університету. 2009. № 5. Т. 2. С. 13-16.

3. Грішнова О.А., Жорова Є.Р. Кадрове забезпечення ефрективної системи антикризового корпоративного управління. Проблеми економіки. 2014. № 1. С. 193-198.

4. Грузіна І.А., Дериховська В.І. Проблеми розвитку персоналу в системі стратегічного управління підприємством : монографрія. Харків : Вид. ХНЕУ ім. С. Кузнеця, 2014. 250 с.

5. Професійний розвиток персоналу підприємств в системі мотиваційного менеджменту : колективна монографрія / М.В. Семикіна, С.В. Дудко, А.А. Орлова та ін. Кропивницький : Видавець Лисенко В.Ф., 2021. 440 с.

6. Shaulska L., Kovalenko S., Allayarov Sh., Sydorenko O., Sukhanova A. Strategic enterprise competitiveness management under global challenges. Academy of Strategic Management Journal. 2021. Vol. 20. Issue 4. P. 1-7.

\section{REFERENCES:}

1. Bei, H.V. (2018) Upravlinnia rozvytkom personalu yak metod zabezpechennia vysokoho rivnia zaluchenosti pratsivnykiv [Personnel development management as a method of ensuring a high level of employee involvement]. Modern Economics, vol. 8, pp. 6-14. (in Ukrainian)

2. Brych, V.Ya. and Huhul, O.Ya. (2009) Teoretychni aspekty rozvytku personalu [Theoretical aspects of staff development]. Visnyk Khmelnytskoho natsionalnoho universytetu, vol. 5, pp. 13-16. (in Ukrainian)

3. Hrishnova, O.A. and Zhorova, Ye.R. (2014) Kadrove zabezpechennia efektyvnoi systemy antykryzovoho korporatyvnoho upravlinnia [Staffing an effective system of anti-crisis corporate governance]. Problemy ekonomiky, vol. 1, pp. 193-198. (in Ukrainian)

4. Hruzina, I.A. and Derykhovska, V.I. (2014) Problemy rozvytku personalu v systemi stratehichnoho upravlinnia pidpryiemstvom [Problems of personnel development in the system of strategic management of the enterprise]: monohrafiia [a monograph]. Kharkiv: Vyd. KhNEU im. S. Kuznetsia, 250 p. (in Ukrainian)

5. Semykina, M.V. (Eds.). (2021) Profesiinyi rozvytok personalu pidpryiemstv v systemi motyvatsiinoho menedzhmentu [Professional development of enterprise personnel in the system of motivational management]: kolektyvna monohrafiia [a monograph]. Kropyvnytskyi: Vydavets Lysenko V.F., 440 p. (in Ukrainian)

6. Shaulska, L., Kovalenko, S., Allayarov, Sh., Sydorenko, O. and Sukhanova, A. (2021) Strategic enterprise competitiveness management under global challenges. Academy of Strategic Management Journal, vol. 20, issue 4 , pp. 1-7. 